\title{
Analysis of factors of smart tourism development in Serbia
}

\author{
Jovana Savić ${ }^{1 *}$, Goran Pavlović \\ ${ }^{1} \mathrm{PhD}$ student, University of Kragujevac, Faculty of Economics \\ ${ }^{2} \mathrm{PhD}$ student, University of Kragujevac, Faculty of Economics
}

\begin{abstract}
The rapid development of information technology has created numerous opportunities for the tourism sector. Smart tourism is one of the latest trends in tourism based on smart technologies. The aim of the research is to analyze the state of the key factors for the development of smart tourism in Serbia. Three factors were selected for the analysis: technology, human capital and innovation. The analysis relies on data on the state of these factors in the past five years from the reports on Serbia's Competitiveness Index and comparing these data with data for countries in which smart city development initiatives have been launched. The conclusion drawn from the analysis is that Serbia has a good basis for the development of smart tourism from the point of view of technology and human capital, but that there is low innovative potential for it. Understanding these factors from the point of view of their past and current development, as well as level of development in relation to the countries in which smart cities exist, can help to determine to what extent and in which ways these factors can be improved in order to create the necessary conditions for development of smart tourism in Serbia.
\end{abstract}

Keywords: smart city, smart tourism, ICTs, factors of development of smart tourism JEL classification: Z32, M15, L83

\section{Analiza faktora razvoja smart turizma u Srbiji}

Apstrakt: Ubrazani razvoj informacionih tehnologija stvorio je brojne mogućnosti za turistički sektor. Pametni turizam je jedan od najnovijih trendova u turizmu zasnovan upravo na pametnim tehnologijama. Cilj istraživanja je da se analizira stanje ključnih faktora razvoja smart turizma u Srbiji. Za analizu su odabrana tri faktora: tehnologija, ljudski resursi i inovacije. Analiza se oslanja na podatke o stanju navedenih faktora u proteklih pet godina iz izveštaja o Indeksu konkurentnosti Srbije i poređenju tih podataka sa podacima za zemlje u kojima su pokrenute inicijative za razvoj pametnih gradova. Zaključak koji je izveden na osnovu analize je da Srbija sa stanovišta tehnologije i ljudskog kapitala ima dobru osnovu za razvoj smart turizma, ali da za to ima nizak inovativni potencijal. Razumevanje ovih faktora sa stanovišta njihove prošle i trenutne razvijenosti, kao i nivoa razvijenosti u odnosu na zemlje u kojima postoje pametni gradovi, može pomoći kako bi se utvrdilo u kom stepenu i na koje načine se ovi faktori mogu unaprediti kako bi se stvorili neophodni uslovi za razvoj smart turizma u Srbiji.

Ključne reči: smart grad, smart turizam, ICTs, faktori razvoja smart turizma JEL klasifikacija: Z32, M15, L83

*jokasavic92@gmail.com 


\section{Introduction}

Information and communication technologies (ICTs) have led to major changes and development of new trends in tourism in the past few years. ICTs have transformed tourism globally and have become key to the competitiveness of tourism organizations and destinations (Buhalis \& O'Connor, 2005). The role of information technology in tourism has evolved from the use of the Internet, through mobile devices, to the use of smart technology that today defines a new era of tourism (Koo et al., 2015), the so-called smart tourism. The concept of smart tourism has evolved from the concept of smart cities that represent the environments in which technology is built into the city in order to increase the quality of life of citizens and to improve the services that the city provides. A smart city is "a new management and development model of urban social systems that features technology integration, industry convergence and intelligent services" (Guo et al., 2014, p. 55).

The concept of smart tourism has not been developed on the territory of Serbia and it is not sufficiently elaborated in domestic literature. The aim of the research is to analyze the state of the key factors for the development of smart tourism in Serbia. Starting from the above, the paper analyzes the factors that are labeled in the literature as the basis for the development of smart tourism (Nam \& Pardo, 2011b; Gretzel et al., 2015b; Boes et al., 2015, 2016), with the analysis being reduced to three factors: technology, innovation and human capital. Relying on reports on Index of competitiveness of Serbia for the period from 20132017 , the paper analyzes the state of the mentioned factors over the five-year period, and then the data is compared with the data for countries with smart city initiatives in order to determine the desired level and way of improving these factors in order to create the conditions for the development of smart tourism in Serbia.

\section{Smart city}

In recent years, we have witnessed the rapid development of the growing urban areas and the increase of the number of their inhabitants. The process of urbanization has led to the fact that more than half of the world's population lives in cities and this number is continuously increasing. The expansion of cities brings with it numerous challenges and problems such as the greenhouse effect, resource exploitation, congested traffic, waste management problems, political and social complexity and so on (Nam \& Pardo, 2011a). Overcoming these problems is possible with the development of an innovative urban management system, which has led to the development of the so-called smart cities. The basis of the concept of smart cities is smartness as the glue that connects mutually beneficial systems and stakeholders and provides an infrastructure for creating value for everyone (Buhalis, 2015). The smart city label indicates the application of smart solutions that enable modern cities to survive through the quantitative and qualitative improvement of their productivity (Caragliu et al., 2009).

The functioning of smart cities is based on the connection of modern information technologies with physical, social and business infrastructure that increases the general intelligence of the city, all in order to improve the operational efficiency and quality of life of citizens. A traditional city with physical infrastructure is becoming a modern city with a virtual infrastructure that allows to collect, integrate and analyze operational data and make decisions based on them (Harrison et al., 2010). Data are collected in real time by sensors, personal devices, cameras, smartphones, social networks, and then these data are integrated using a computer platform to obtain information transmitted to different city sectors. The normal functioning of such cities requires not only high-tech equipment and infrastructure, but also adequate support from the city authorities, active participation of more educated and 
better-informed citizens and their communities in city governance and technology use, an appropriate level of economic development, environmental protection etc.

\section{Smart tourism}

Recognizing the potential of intelligent technologies, as well as the need to adapt business to accelerated technological changes, companies from the tourism sector have begun implementing the smart concept in order to improve business and create a sustainable competitive advantage. The introduction of smart technologies into the business of tourism organizations changed the experience of tourists, but it also allowed to generate more creative business models. The phenomenon of smart tourism has evolved as a result of the integration and infiltration of smart technology into the tourism sector. The innovations that come out of this integration mainly relate to the intelligent hotel management system, the intelligent ticketing system, the intelligent remote video monitoring system, the intelligent tour guide system and the intelligent travel agency system (Guo et al., 2014).

In the previous research, the authors singled out certain characteristics of smart tourism (Graziano, 2014). First of all, tourists can orient themselves using smart devices. Smart tourism transforms tourists into intelligent and active participants in the production of a tourism product. Furthermore, smart tourism points to the application of a multi-channel approach as an interface between real and virtual space. Also, smart tourism provides tourists with the opportunity to interact with the local population or other tourists. In addition to these, smart tourism has other features (Hunter et al., 2015). It allows tourism product to be available to tourists more quickly via e-commerce, to make tourism destinations more accessible to visitors through GPS navigation, make information more interactive, new resources available, and increases the attractiveness of destinations through their online representation through websites or social media. In addition to providing tourists with a different experience, smart tourism provides benefits from the business side. Here, one can distinguish a new way of managing tourist trends, providing better tourist services, applying new promotion models and accessing open databases (Gretzel et al., 2016).

Considering that smart tourism is a relatively new concept that is still developing, several challenges that it faces can be identified (Gretzel et al., 2015a). One of the most important challenges for smart tourism is the dependence of the experience of tourists and technology. This practically means that the experience depends on whether the tourists use smart devices that can run applications that allow the delivery of smart services. Also, the important issue is about accessing smart devices to sources of electricity so that their batteries can last long enough to connect the tourist to the destination. The next question is about what the experience will have tourists who do not have the appropriate smart devices or who want to enjoy their travel without using smart devices. The problem often exists in relation to the investments that must be provided in order to develop the appropriate infrastructure for the development of smart tourism. The problem of investments is related to the problem of controlling the system of data usage, that is, the protection and confidentiality of data from citizens and tourists.

\section{Smart tourism destinations}

Smart tourism includes two essential elements: smart technology and smart destination. The term smart tourism destination implies "an innovative tourist destination, built on an infrastructure of state-of-the-art technology guaranteeing the sustainable development of tourist areas, accessible to everyone, which facilitates the visitor's interaction with and integration into his or her surroundings, increases the quality of the experience at the destination, and improves residents' quality of life" (Gretzel et al., 2015a, p. 43). The concept 
of smart destinations is derived from the smart city concept and is still in development. It is about "the modern integrated management of destinations, using technology to optimize resources and develop new strategies based on more 'bottom-up' approaches" (Micera et al., 2013 , p. 1408). This approach allows destination managers to work together with tourists to jointly create a tourism experience, whereby tourists are allowed to share information and knowledge with each other in order to have more chances to develop new experiences. For this reason, a smart destination offers tourists much more than an ordinary destination.

A smart tourism destination successfully implements smartness, which is stimulated by open innovations, investments in human and social capital and participatory governance, in order to develop the collective competitiveness of tourism destination and thereby enhance social, economic and environmental prosperity for all stakeholders (Buhalis, 2015). Its main priorities from the standpoint of demand and supply are: enhancing the tourist's travel experience, providing intelligent platforms for collecting and distrubution information among key stakeholders, the efficiency and effectiveness of tourism resources allocation and integration of the tourism suppliers to ensure that the profit from tourism is equally distributed within the local society (Del Chiappa \& Baggio, 2015).

\section{Factors of development of smart tourism in Serbia}

As mentioned above, smart tourism destinations are a special form of smart cities, that is, they apply the same principles and infrastructure that are characteristic of these cities. Consequently, the basic components or factors of development of smart cities are at the same time factors of development of smart tourism destinations as an element of smart tourism. Various factors of their development are given in the literature. Nam and Pardo (2011b) observe technology, human capital and institutional framework as the fundamental components of smart cities. Gretzel et al. (2015b) deal with the analysis of the technological and business basis of smart tourism. In their research, Boes et al. (2015, 2016) explore innovation, human and social capital, leadership and entrepreneurship as the main pillars of smart destinations. Starting from the above, in this paper, technology, human capital and innovation will be analyzed, since these factors are considered as fundamental constructs from the standpoint of the development of smart tourism in Serbia.

\subsection{Technology}

Contemporary ICTs are undoubtedly the key component of the development of smart tourism. Smart technology allows to gather information, generate knowledge quickly and adequately respond to new situations. Therefore, smart tourism destinations are regarded as knowledge-intensive destinations in which information technologies are used to provide instruments, platforms and systems that make knowledge and information accessible to all stakeholders in a systematic and efficient manner, and which provide mechanisms for stakeholder participation in innovative process (Del Chiappa \& Baggio, 2015). Tourism organizations in smart environment must adapt their products and marketing strategy to technology because it is one of the trends in the environment that shapes the behaviour of future tourists (Senić \& Manojlović, 2017).

In the period of rapid development of information technologies, Serbia was going through a poor economic and political situation, which slowed down the process of their adoption. Today, however, there is a certain degree of technological development and application of information technologies in most business sectors, even in tourism, but Serbia still lags behind in comparison with the world. The level of technological development of Serbia will be analyzed based on the data from the report on the Competitiveness Index of Serbia for a five-year period $(\underline{2013}, \underline{2014}, \underline{2015}, \underline{2016}, \underline{2017})$. In particular, based on the report, the ninth 
pillar of competitiveness will be analyzed, designated as Technological readiness. It measures the readiness of the economy to adopt existing technologies in order to increase the productivity of the industry, with special emphasis on its capacity to use ICTs in everyday activities and production processes in order to increase efficiency and enable innovation (WEF, 2015). Table 1 shows the collected data for the specified pillar, where it is important to note that the values are in the range from 1-7.

Table 1: Competitiveness Index for pillar Technological readiness (2013-2017)

\begin{tabular}{|l|c|c|c|c|c|}
\hline Year & $\mathbf{2 0 1 3}$ & $\mathbf{2 0 1 4}$ & $\mathbf{2 0 1 5}$ & $\mathbf{2 0 1 6}$ & $\mathbf{2 0 1 7}$ \\
\hline Technological readiness & 3.94 & 4.45 & 4.47 & 4.05 & 4.19 \\
\hline
\end{tabular}

Source: Tanasković \& Ristić, 2013, 2014, 2015, 2016, 2017

Beginning from 2013, data on Serbia's technological capabilities point to small but significant progress. In 2014, progress was achieved in five segments compared to the previous year, and the largest in technological segment. This growth was accompanied by an increase in all elements of the technology pillar of competitiveness, with the greatest contribution being achieved within objective indicators related to the number of Internet users, the average amount of data transmitted per user and the number of mobile Internet users (Tanasković \& Ristić, 2014). However, the negligible changes in the observed pillar were recorded in 2015 compared to 2014. In 2016, the index value had a significant drop and Serbia fell on the ranking list of countries by pillars by as much as 19 places, i.e. from the 51st place in 2015 to 70 th place. According to the latest report, in 2017, the technological readiness of Serbia improved compared to the previous year as a result of the availability of modern technologies and the transfer of new technologies through foreign direct investments, increased participation of Internet users, increased participation of users with fixed access to high speed internet as well as the amount of data per user of the Internet, while the deterioration was recorded in the number of mobile subscribers per hundred inhabitants (Tanasković \& Ristić, 2017). If on the scale from 1-7 we consider all values from 1 to 4 as unfavourable, 4 as neutral, and values from 4 to 7 as favourable, it could be concluded that Serbia's technological readiness according to the index value of 2017 is favourable.

In addition to the above, for the purpose of more precise analysis of technological readiness, comparison of the values of the Competitiveness Index of Serbia in 2017 for pillar Technological readiness with indexes of countries where there are smart cities such as USA, Great Britain, Japan and China can be made (Table 2).

Table 2: Competitiveness Index value for pillar Technological readiness across nations in 2017

\begin{tabular}{|c|c|}
\hline Country & Competitiveness Index value \\
\hline USA & 6.23 \\
\hline Great Britain & 6.33 \\
\hline Japan & 6.01 \\
\hline China & 4.18 \\
\hline
\end{tabular}

Source: WEF, 2017

Comparing to the value of the Index in our country (4.19), these three countries are at a significantly higher level of technological readiness. However, it can be said that the situation is not so bad given that the technological readiness of the observed countries on the scale from 1-7 can be described as favourable, as in Serbia. In favour of this, if the value of the Index for the analyzed pillar was compared to China, it can be seen that they are almost the same, which shows that Serbia has a good technological basis for the development of smart tourism. However, it is possible to make recommendations for improving the 
technological readiness of the country, which would significantly benefit not only the tourism sector, but also the entire economy. One of the ways that is considered to be able to contribute to technological readiness is the 'brain drain', since "studies over the last two decades had shown that 'brain drain' can have a positive effect on the economy due to the spillover effect of know-how and new technologies from developed economies, through workers who decide to return to the country" (Ristić \& Tanasković, 2011, p. 76). If we look at 2014 and 2017 in which Serbia has made significant progress in the field of technology, it can be pointed out that it is necessary to work on attracting new foreign direct investments that will enable the transfer of technology, as well as the increase in the number of Internet and mobile Internet users, which is particularly important for the functioning of smart tourism. Also, work on projects that are oriented towards the development of technology and innovation can be of great importance for the improvement of technological readiness. In addition to the existing ones, it is advisable to apply for funding for new projects under the auspices of the Innovation Fund, the Ministry of Science, Education and Technological Development and other institutions.

\subsection{Human capital}

As urban tourism regions, smart tourism destinations are seen as complex ecosystems in which different actors work together to create value. They emphasize the link between society and technology, where people and technology are considered as equal participants who together create economic, social and environment prosperity (Boes et al., 2016). Economic growth, improvement of the quality of life of citizens and the stay of tourists must be supported by developed human capital. Given that tourism destinations are economies based on knowledge and that people are key knowledge holders, human capital is an essential element of the strategy for the development of smart cities and smart destinations. The smart city label actually refers to the capacity of smart people to find smart solutions to urban problems (Albino et al., 2015). The human factor in smart destinations refers to creativity, social learning and education, whereby education is considered crucial to increasing the attractiveness of the destination. Technology itself cannot make the city or destination smarter - it is made up of people and their interaction that allows the development of collective intelligence.

Despite the fact that in Serbia, as in most countries in the world, the importance of human resources and their potential is recognized, this topic has often been insufficiently analyzed or completely ignored in the field of tourism. The problems caused by the wars and crises of the past decades have further exacerbated the state of human capital in Serbia. Today, it can be said that the conditions of human capital development have improved to a certain extent as a result of various initiatives and legal measures. In this paper, for the analysis of human capital, the fifth pillar of competitiveness i.e. Higher education and training will be considered from the report on the Competitiveness Index of Serbia. This pillar measures the secondary and tertiary enrollment rates, the quality of education and the scope of staff training, and points to the importance of educated and trained workers for performing complex tasks and quick adaptation in a changing environment (WEF, 2015). Table 3 gives data on the movement of the index value for this pillar in the range from 1-7.

Table 3: Competitiveness Index for pillar Higher education and training (2013-2017)

\begin{tabular}{|l|c|c|c|c|c|}
\hline Pillar Year & $\mathbf{2 0 1 3}$ & $\mathbf{2 0 1 4}$ & $\mathbf{2 0 1 5}$ & $\mathbf{2 0 1 6}$ & $\mathbf{2 0 1 7}$ \\
\hline Higher education and training & 4.05 & 4.25 & 4.27 & 4.40 & 4.55 \\
\hline
\end{tabular}

Source: Tanasković \& Ristić, 2013, 2014, 2015, 2016, 2017 
When looking at the index values for the analyzed pillar in the observed period, a certain increase in value is observed. In 2013 there were no significant developments in the area of higher education and training compared to the previous years. However, 2014 is the year of significant fifth-pillar growth, and the improvement is achieved due to a higher rate of enrollment in higher education institutions and increased access to the Internet in schools (Tanasković \& Ristić, 2014). In 2015, there were no significant changes in this pillar compared to the previous year. Observed in 2016, progress has been noted for 2 places on the ranking list, due to the increase in the quality of the education system, the quality of education in the field of mathematics and science, the availability of different courses for specialization of workers, and slightly higher enrollment rates in the tertiary level of education compared to the previous year (Tanasković \& Ristić, 2016). In 2017, the improvement of the pillar results from a better quality of the education system, studies in mathematics and natural sciences, management schools, as well as access of the Internet in schools, the availability of training services and the level of employee training (Tanaskovic \& Ristić, 2017). Finally, it can be said that according to the value of the Index from the last year on the scale from 1-7, Serbia can be designated as a country in which the situation from the point of view of higher education and training is favourable.

A more detailed analysis of human capital will be based on the comparison of the value of the Index of Serbia for the observed pillar (4.55) with the Index values of the United States, Great Britain, Japan and China.

Table 4: Competitiveness Index value for pillar Higher education and training across nations in 2017

\begin{tabular}{|c|c|}
\hline Country & Competitiveness Index value \\
\hline USA & 6.12 \\
\hline Great Britain & 5.48 \\
\hline Japan & 5.38 \\
\hline China & 4.78 \\
\hline
\end{tabular}

Source: WEF, 2017

Index values show that Serbia does not lag too much behind Great Britain and Japan in terms of higher education and training, while in relation to the United States it is on a much lower level. However, as all four countries on the scale from 1-7 can be designated as countries where the situation for this pillar is favourable, it is concluded that Serbia has a good potential for developing smart tourism in the context of human resources. Additionally, by comparing the Index value for Serbia with the Index value for China, it can be seen that the level of development of higher education and training in China is not much higher than in Serbia, which also shows that human capital in Serbia can be an appropriate basis for the development of smart tourism. Despite this, recommendations for improvement can also be made in this domain. The most important one is improvement of the quality of the education system, the introduction of the Internet into a larger number of educational institutions, and an increase in the number and diversity of training for employees. In order to improve the quality of knowledge and abilities of pupils and students, it is of particular importance to introduce a dual education system. As people are the main bearers of innovation, "Serbia needs education that will enable individuals to learn and develop a wide range of skills needed for innovation in all its forms" (Balšić, 2016, p.93). Good practice certainly applies to the development of new institutes and research centres and the realization of greater cooperation between companies, universities and research institutions. 


\subsection{Innovation}

One of the key goals of smart cities and smart destinations is to promote entrepreneurship and innovation. Innovation is at the same time the most important input and a result of the integration of smart technologies and cities. It develops when all smart factors work together on it, and its significance is reflected in the fact that it is key to the competitiveness of smart cities and smart tourism destinations (Boes et al., 2016). Innovations that emerge as a result of the development of ICTs have a great importance for the development of smart tourism because, on the one hand, they enable tourists to navigate easier in a smart environment, while on the other hand, they enable the environment to get information about tourists more easily. In addition, innovations in the field of smart technology are important for the social dimension, since they allow tourists to contact their family and friends at any time and share their experience with them. Innovations are based on the assumption that tourism organizations cannot rely solely on their own resources, but must co-operate beyond their borders to develop innovation (Gretzel et al., 2015b). Only in this way can be provided and exchanged the resources needed to create value within smart destinations.

As technology is the key driver of innovation and in Serbia, compared to the world, it is not well developed, the innovative potential of our country is also not at a high level. The reason is not only the state of technology, but also the lack of financial resources, the absence of entrepreneurial spirit and so on. However, it is undeniable that there are initiatives for the development of innovation and entrepreneurship or that efforts are being made to improve this area. The analysis of the innovative potential of Serbia was made on the basis of the data on the values of the Competitiveness Index of Serbia (Table 5, ranking from 1-7) in the fiveyear period for the last, twelfth pillar of the Index i.e. Innovation. It refers to investments in research and development, the presence of high-quality scientific-research institutions, cooperation between universities and industries in the field of research and technological development and intellectual property protection ( $\underline{\mathrm{WEF}, 2015})$.

Table 5: Competitiveness Index for pillar Innovation (2013-2017)

\begin{tabular}{|l|c|c|c|c|c|}
\hline Pillar Year & $\mathbf{2 0 1 3}$ & $\mathbf{2 0 1 4}$ & $\mathbf{2 0 1 5}$ & $\mathbf{2 0 1 6}$ & $\mathbf{2 0 1 7}$ \\
\hline Innovation & 2.85 & 2.89 & 2.90 & 2.97 & 3.11 \\
\hline
\end{tabular}

Source: Tanasković \& Ristić, 2013, 2014, 2015, 2016, 2017

As with the previously analyzed factors, Serbia made small progress in the development of innovation in the observed period. 2013 was not significant for the development of the country's innovative potential. From 2014-2015, there were also no significant changes. Compared to 2015, in 2016 Serbia fell on the rankings of the countries by 5 places despite the increase in the index value. Finally, in 2017, innovation had the highest index growth. Innovative potential of the country according to the value of the Index from the last year on the scale from 1-7 can be marked as unfavourable.

Innovation will be further analyzed on the basis of the comparison of the value of the Index for the pillar Innovation.

Table 6: Competitiveness Index value for pillar Innovation across nations in 2017

\begin{tabular}{|c|c|}
\hline Country & Competitiveness Index value \\
\hline USA & 5.82 \\
\hline Great Britain & 5.06 \\
\hline Japan & 5.37 \\
\hline China & 4.14 \\
\hline
\end{tabular}

Source: WEF, 2017 
Compared with the United States, Great Britain and Japan, it can be seen that Serbia lags behind them in terms of innovation. In addition, unlike those countries where the innovative potential on the scale from 1-7 can be marked as favourable, the Index value below 4 shows that it is unfavourable in Serbia. Also, our country compared to China has a much weaker developed innovative potential. Therefore, it can be concluded that Serbia from the point of view of innovative potential does not have an adequate basis for the development of smart tourism and that it is necessary to work on its improvement. For development of innovative capabilities, our country can be led by examples from the world, such as the $22 @$ Barcelona district, where various institutions and companies are collaborating in the development of urban innovation, or Living Lab in Amsterdam, where citizens, scientists and academics work together on developing product and services that will improve the quality of life (Boes et al., 2015). Also, more work needs to be done on the development of innovation policies in order to create the necessary conditions and measures to encourage the country's innovative potential. Given that technology and innovation are closely linked, working on existing and application for new projects can provide the necessary funding for investment in research and development. On the other hand, starting from the link between innovation and human capital, greater cooperation between universities and industrial sectors in the field of research and technological development should be promoted.

\section{Conclusion}

Smart tourism is a new trend in the tourism industry based on a strong technology infrastructure, which in combination with factors such as physical infrastructure, human, social and business capital, provides conditions for creating value for different stakeholders. Starting from the above, this paper analyzes technology, human capital and innovation as factors that are considered to be the most important for the development of smart tourism. The analysis has showed that the technological readiness of Serbia does not lag too much behind the countries where there are smart cities, and that the state of human capital is quite suitable for initiating the development of smart tourism. However, from the point of view of innovative capabilities, Serbia is in a worse position compared to the countries surveyed, which is why it is concluded that in this domain there is no good basis for the development of smart tourism.

It can be said that work has a double contribution. The first refers to the study of the concept of smart tourism, its characteristics and challenges it faces, and the factors that form the basis of its development. In this way, the gap that exists in domestic research literature has been overcome to a certain extent, which has not paid too much attention to this concept, both theoretically and practically. The second contribution is reflected in the practical applicability of the work. Primarily, managers havepointed out the importance of introducing a smart concept into business in order to provide better tourism services and improve the competitive position, as well as the importance of integrating the analyzed factors in order to create value in tourism destinations. The contribution of the conducted analysis implies that it can help both governments and companies in the tourism industry to understand the importance of smart tourism, the condition of the factors that ensure its development and recommendations for their improvement. This can increase the interest in this concept, which would result in the launch of an initiative for the development of smart tourism and the improvement of Serbia's tourist offer in the future. In addition to the contribution, the work has several limitations. The first is the omission of the remaining factors that are considered to be the basis of smart tourism such as social capital, business infrastructure or entrepreneurship. Furthermore, the paper does not cover all questions related to the concepts being explored. Another disadvantage is that the analysis relies only on the data from the Competitiveness Index of the countries covered by it. Also, Serbia is compared with only four countries. In line with the above, the following recommendations for future research are 
given. In relation to the concepts mentioned in the paper, which are smart city, smart tourism, smart tourism destinations and factors of development, it is necessary to conduct more detailed research and analysis of the aspects that are not covered by this work (personalization of services, competitiveness of smart tourism destinations, analysis the preference of tourists, the role of social media in smart destinations etc.). As for the analysis itself and the data on which it is based, it is desirable that in future works it relies on data from other World Economic Forum Reports such as the Global Human Capital Report, the Global Information Technology Report, the Travel and Tourism Competitiveness Report, the Global Innovation Index, the Global Entrepreneurship Index etc. Finally, it is desirable to include the remaining factors and a larger number of countries in the analysis in order to more precisely compare and determine the state of the factors of the development of smart tourism in Serbia.

\section{References}

1. Albino, V., Berardi, U. \& Dangelico, R. M. (2015). Smart cities: Definitions, dimensions, performance, and initiatives. Journal of Urban Technology, 22(1), 3-21. https://doi.org/10.1080/10630732.2014.942092

2. Balšić, S. (2016). Competitiveness of the Republic of Serbian economy. Ekonomski signali: poslovni magazin, 11(1), 81-94. https://doi.org/10.5937/ekonsig1601081B

3. Boes, K., Buhalis, D. \& Inversini, A. (2015). Conceptualising smart tourism destination dimensions. Information and communication technologies in tourism, 391-403. https://doi.org/10.1007\%2F978-3-319-14343-9_29

4. Boes, K., Buhalis, D. \& Inversini, A. (2016). Smart tourism destinations: ecosystems for tourism destination competitiveness. International Journal of Tourism Cities, 2(2), 108-124. https://doi.org/10.1108/IJTC-12-2015-0032

5. Buhalis, D. (2015). Working Definitions of Smartness and Smart Tourism Destination, Buhalis Blog http://t.co/xrLRpGipvu, February 10, 2015. Retrieved December 6, 2017 from http://buhalis.blogspot.rs/2014/12/working-definitions-of-smartness-and.html

6. Buhalis, D. \& O'Connor, P. (2005). Information communication technology revolutionizing tourism. Tourism recreation research, 30(3), 7-16. https://doi.org/10.1080/02508281.2005.11081482

7. Caragliu, A., Del Bo, C. \& Nijkamp, P. (2009). Smart cities in Europe. 3rd Central European Conference in Regional Science - CERS, 65-82.

8. Del Chiappa, G. \& Baggio, R. (2015). Knowledge transfer in smart tourism destinations: analyzing the effects of a network structure. Journal of Destination Marketing \& Management, 4(3), 145-150.

https://doi.org/doi:10.1016/j.jdmm.2015.02.001

9. Graziano, T. (2014). Boosting innovation and development: the Italian Smart Tourism, a critical perspective. European Journal of Geography, 5(4), 6-18. http://dx.doi.org/10.13138/2039-2362/1409

10. Gretzel, U., Reino, S., Kopera, S. \& Koo, C. (2015a). Smart tourism challenges. Journal of Tourism, 16(1), 41-47.

11. Gretzel, U., Sigala, M., Xiang, Z. \& Koo, C. (2015b). Smart tourism: foundations and developments. Electronic Markets, 25(3), 179-188. https://doi.org/10.1007/s12525-0150196-8

12. Gretzel, U., Zhong, L. \& Koo, C. (2016). Application of smart tourism to cities. International Journal of Tourism Cities, 2(2). https://doi.org/10.1108/IJTC-042016-0007

13. Guo, Y., Liu, H. \& Chai, Y. (2014). The embedding convergence of smart cities and tourism internet of things in China: An advance perspective. Advances in Hospitality and Tourism Research, 2(1), 54-69. 
14. Harrison, C., Eckman, B., Hamilton, R., Hartswick, P., Kalagnanam, J., Paraszczak, J. \& Williams, P. (2010). Foundations for smarter cities. IBM Journal of Research and Development, 54(4), 1-16. https://doi.org/10.1147/JRD.2010.2048257

15. Hunter, W. C., Chung, N., Gretzel, U. \& Koo, C. (2015). Constructivist research in smart tourism. Asia Pacific Journal of Information Systems, 25(1), 105-120. https://doi.org/10.14329/apjis.2015.25.1.105

16. Koo, C., Gretzel, U., Hunter, W. C. \& Chung, N. (2015). The role of IT in tourism. Asia Pacific Journal of Information Systems, 25(1), 99-104.

http://doi.org/10.14329/apjis.2015.25.1.099

17. Micera, R., Presenza, A., Splendiani, S. \& Del Chiappa, G. (2013). SMART Destinations. New strategies to manage tourism industry. In International Forum on Knowledge Asset Dynamics IFKAD, vol. 19, (pp. 1405-1422).

18. Nam, T. \& Pardo, T. A. (2011a). Smart city as urban innovation: Focusing on management, policy, and context. In Proceedings of the 5th international conference on theory and practice of electronic governance. (pp. 185-194). Tallinn, Estonia. https://doi.org/10.1145/2072069.2072100

19. Nam, T. \& Pardo, T. A. (2011b). Conceptualizing smart city with dimensions of technology, people, and institutions. In Proceedings of the 12th annual international digital government research conference: digital government innovation in challenging times. (pp. 282-291). College Park, Maryland, USA. https://doi.org/10.1145/2037556.2037602

20. Ristić, B. \& Tanasković, S. (2011). Konkurentnost Srbije: merenje konkurentnosti i rangiranje zemalja prema izveštaju Svetskog ekonomskog foruma. [Serbia's Competitiveness: measuring competitiveness and ranking countries according to the report of the World Economic Forum ]. Kvartalni monitor, br. 25-26, 68-80.

21. Senić, V. \& Manojlović, N. (2017). Savremene tendencije u turizmu. [Contemporary tendencies in tourism]. Menadžment u hotelijerstvu i turizmu, 5(1), 18-27.

22. Tanasković, S. \& Ristić, B. (2013). Konkurentska pozicija Srbije u 2013. godini prema Izveštaju Svetskog ekonomskog foruma. [Competitive position of Serbia in 2013 according to the Report of the World Economic Forum]. Fondacija za razvoj ekonomske nauke, Beograd.

23. Tanasković, S. \& Ristić, B. (2014). Konkurentska pozicija Srbije u 2014. godini prema Izveštaju Svetskog ekonomskog foruma. [Competitive position of Serbia in 2014 according to the Report of the World Economic Forum]. Fondacija za razvoj ekonomske nauke, Beograd.

24. Tanasković, S. \& Ristić, B. (2015). Konkurentska pozicija Srbije u 2015. godini prema Izveštaju Svetskog ekonomskog foruma. [Competitive position of Serbia in 2015 according to the Report of the World Economic Forum]. Fondacija za razvoj ekonomske nauke, Beograd.

25. Tanasković, S. \& Ristić, B. (2016). Konkurentska pozicija Srbije u 2016. godini prema Izveštaju Svetskog ekonomskog foruma. [Competitive position of Serbia in 2016 according to the Report of the World Economic Forum]. Fondacija za razvoj ekonomske nauke, Beograd.

26. Tanasković, S. \& Ristić, B. (2017). Konkurentska pozicija Srbije u 2017. godini prema Izveštaju Svetskog ekonomskog foruma. [Competitive position of Serbia in 2017 according to the Report of the World Economic Forum]. Fondacija za razvoj ekonomske nauke, Beograd.

27. WEF (2015). Global Competitiveness report 2015-2016. Retrieved December 10, 2017 from http://reports.weforum.org/global-competitiveness-report-2015-2016/

28. WEF (2017). Global Competitiveness report 2017-2018. Retrieved December 10, 2017 from https://www.weforum.org/reports/the-global-competitiveness-report-2017-2018

Received: 13 March 2018; Sent for revision: 16 April 2018; Accepted: 7 May 2018 